\title{
DIGITAL METHODS OF REAL ESTATE ASSET LIFECYCLE MANAGEMENT
}

\author{
Irina VLADIMIROVA ${ }^{1}$, Galina KALLAUR ${ }^{2}$, Kseniia BARESHENKOVA ${ }^{3}$ \\ ${ }^{1-3}$ Plekhanov Russian University of Economics, Moscow, Russia \\ Corresponding author's e-mail: kallaur_galina@mail.ru
}

\begin{abstract}
Contemporary scientific research and practical experience in the field of investment and construction projects management prove advisability of planning management processes, including key directions such as scope, time and cost management throughout the lifecycle of a real estate asset. Under conditions of construction industry integration into digital environment and active search for innovative and high-tech ways of development, an urgent issue is to select effective digital methods and tools that correspond to each phase of real estate asset lifecycle and ensure interests of each participant of investment and construction project. The aim of the article is to investigate the digital methods of real estate asset lifecycle management. Through methods of analysis and systematization, the authors of the article have identified that internationally known software producers as well as the scientific community and some representatives of construction industry acknowledge the effectiveness of the currently relevant information modelling technologies (BIM); however, full implementation of BIM technologies in Russia is mainly restrained by low interest from most participants of investment and construction projects. Therefore, by applying methods of comparative analysis and statistical assessments, reported effects of BIM implementation, according to the international experience, have been compared with actual results received by Russian companies, which actively use information modelling technologies. In addition, systematization of modern digital methods and tools for real estate assets management in correspondence with aims of each phase of their lifecycle has been carried out within the framework of the research. As a result, factors for encouragement of BIM implementation based on the principles of publicprivate partnership have been formulated and, in conclusion, respective stimulation measures proposed.
\end{abstract}

Keywords: Digital methods, digital model of building, project participants, real estate asset lifecycle.

\section{INTRODUCTION}

Russia has entered the 21 st century as a country where information society is developing rapidly. In 2002, the Russian Government adopted the Federal Target Program "Electronic Russia 2002-2010", which gave a powerful impetus to the development of information society in regions of Russia. Currently, the main strategic planning documents that form the direction of development of digital technologies in Russia are the "Strategy for Development of Information Society in the Russian Federation for 2017-2030”, "The Strategy for Innovative Development 
of the Russian Federation for the Period to 2020" (Pravitelstvo Rossiiskoi Federatsii, 2011) and the programme "Digital Economy of the Russian Federation".

Under such conditions, the use of information modelling technologies (BIM) in the implementation of investment and construction projects is a relevant issue and an innovative way of development for construction industry as a whole, which has determined the aim of the present research.

Attaching great importance to the development of information modelling in construction, in 2014 the Ministry of Construction, Housing and Communal Services of the Russian Federation (MCHCS) approved the plan for the phased introduction of information modelling technologies in the field of industrial and civil construction (Ministry of Construction, Housing and Communal Services of the Russian Federation, 2014). In 2017, a series of codes on building information modelling was developed, particularly defining the rules for organisation of work by the production and technical departments; descriptions of components of an information model; exchange between information models of real estate assets and models used in software complex programmes; development of project plans implemented with the use of information modelling technologies at different stages of the asset lifecycle (MCHCS, 2017). In 2017, the state standards of the "Building and Structure Information Modelling" series were also approved: GOST R ISO 29481-1-2010 "Information Delivery Manual. Methodology and Format"; GOST R ISO 16354 "Guidelines for Knowledge Libraries and Object Libraries"; GOST R ISO 12006-2017-02-20 "Model of Construction Works Data Organisation"; GOST R ISO 12911-2017-03-21 "General Principles for the Development of Building and Construction Information Modelling Standards"; GOST R ISO 22263-2017-02-28 "Model of Construction Works Data Organisation. The structure of Project Information Management" (GOST R, 2016; GOST R, 2016; GOST R, 2017; GOST R, 2017).

Methods of information modelling are actively used in many countries around the world. More than $70 \%$ of construction market participants announced the use of information modelling technologies in their projects in the US in 2012 (according to the research of McGraw Hill Construction) and $54 \%$ respectively in the UK in 2016 (according to NBS, National BIM Report). According to Singapore's Building and Construction Authority (BCA), since 2015 more than $80 \%$ of all construction projects have been performed exclusively using BIM technologies, and currently all $(100 \%)$ design organisations and about $70 \%$ of construction contractors in Singapore use BIM in their projects.

At the same time, for the current stage of development of project management methodology, which provides basic principles for implementation of investment and construction activities, the need for optimising costs and selecting high-tech solutions makes approaches to managing key project parameters (such as scope, time and cost) over the whole lifecycle of real estate assets even more relevant than earlier. Thus, such methodologies as Total Cost Management (TCM), Product Lifecycle Management (PLM), Whole Life Appraisal (WLA), Life Cycle Costing (LCC) (Kallaur, 2018) have gained popularity around the world and in alliance with BIM currently form a common approach to information modelling and building lifecycle management - Building Lifecycle Management (BLM) (see Fig. 1). 


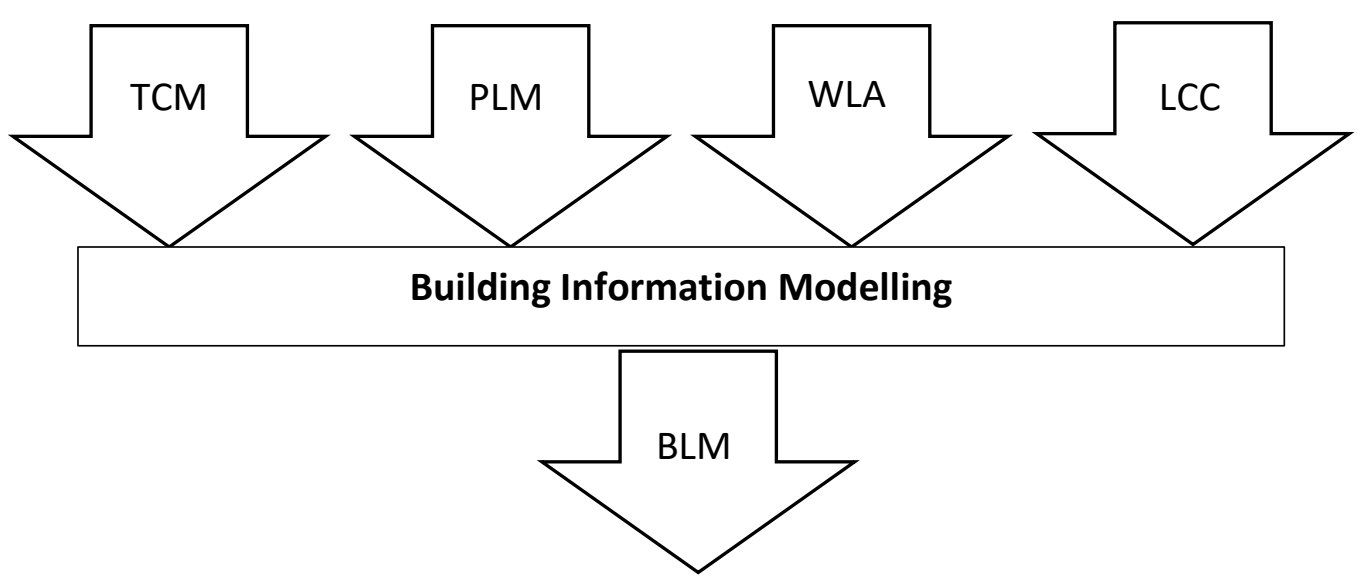

Fig. 1. Formation of building lifecycle management methodology (developed by the authors)

Introduction and application of information modelling technologies are supported at the state level in many countries. That being said, governments aim at reducing construction costs and duration, and encouraging activities for real estate assets to become more environmentally friendly and efficient. International experience of using BIM for investment and construction projects, as well as the world's top software manufacturers and the scientific community prove that achieving these goals is possible (McGraw Hill Construction, n.d.; "Primenenie BIM-tekhnologii pri stroitelstve Dongdaemun Design Plaza”, 2018; Eroshkin, Kallaur, Papikyan, 2017; Sukhorukov, Eroshkin, Kallaur, Papikyan, 2018). However, full implementation of BIM in Russia in many aspects is constrained by low interest from the majority of participants engaged in investment and construction projects. Such conditions make it relevant to find and justify effective methods and tools, which correspond to each phase of a real estate asset lifecycle and ensure high interest of each participant of a project.

\section{METHODS AND PROCEDURES}

Using methods of analysing and systematising regulatory acts and scientific literature, statistical data and international experience of companies delivering projects based on BIM, the authors of the paper have established that application of information modelling technologies causes a number of effects of both commercial and general economic nature, which occur at the project design and construction stage up to the use period and excess of a real estate asset.

Implementation of BIM technologies within the concept of real estate asset lifecycle management also requires research and systematization of digital methods and their distribution among the lifecycle phases, for which application of BIM technologies is most appropriate and effective depending on their type, focus and taking into account the interests of beneficiaries. 
Methods of comparative analysis and statistical assessments have also been used in the research to compare the reported effects of BIM implementation according to the international experience with the actual results of Russian companies actively using information modelling technologies.

\section{ANALYSIS OF BIM APPLICATION EFFECTIVENESS}

Information modelling technologies have been actively applied around the world since 1980s, so it enables the analysis of the accumulated experience in this field and assessment of BIM application effectiveness for different types of projects and for different stakeholders.

For instance, according to the research by McGraw Hill Construction (McGraw Hill Construction, n.d.), the effectiveness of using BIM in North American companies is determined by a number of effects shown in Figure 2. These statistics illustrate the global experience in assessing the effectiveness of using information modelling technologies.

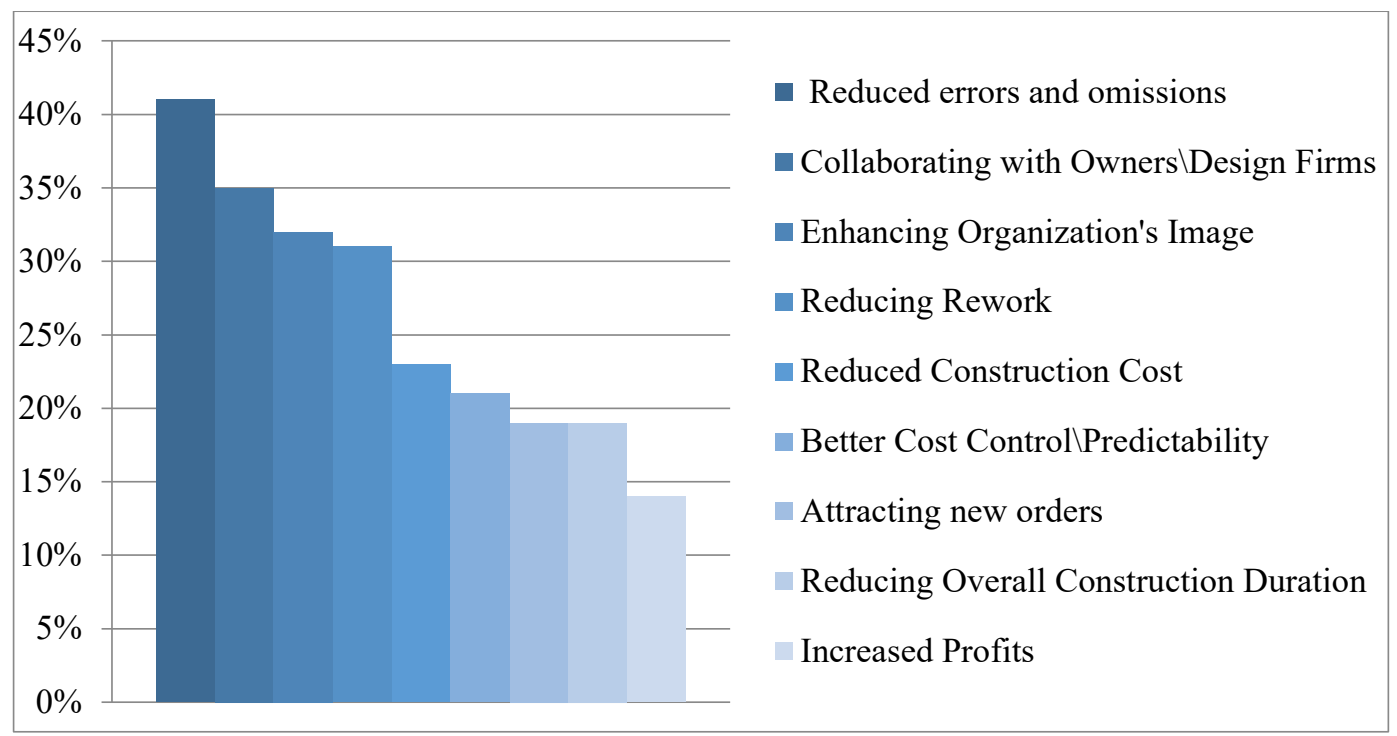

Fig. 2. Criteria determining BIM effectiveness in construction companies of Northern America, \% (McGraw Hill Construction, n.d.).

Despite the fact that introduction of information modelling in Russia has begun later than in average around the world, nowadays Russian design and construction companies have enough accumulated experience in this sphere, which enables comparison of their benefits gained from using BIM in investment and construction projects and respective effects announced by companies in another countries.

To carry out the comparison, the following main effects confirmed by international statistical data (McGraw Hill Construction, n.d.; "Primenenie BIMtekhnologii pri stroitelstve Dongdaemun Design Plaza", 2018; "Rising to new heights with BIM", n.d.) are selected by the authors: 
1. Reduction in construction costs by $25 \%-30 \%$;

2. Reduction in design and construction duration by $15 \%-18 \%$;

3. Increase in profits of companies implementing BIM by $12 \%-17 \%$.

In addition, a number of non-economic advantages of using BIM are noted. Intelligent parameterization, ability to match the construction process to time and budgeting, ability to automatically issue drawings and specifications, as well as absolute interest in information modelling demonstrated by all project participants are among them (Novokovskii, 2015).

Thus, the following step of research is to compare these claimed advantages with the experience of applying information modelling technologies by Russian companies.

Concerning the reduction of a construction project cost when using BIM, it should be noted that according to the Western system of construction cost estimation the project cost at the initiation stage is estimated based on assumption that it varies from $-30 \%$ to $+30 \%$ in relation to the final cost of the project. Therefore, the project cost reduction in range of $25 \%-30 \%$ resulting from the use of BIM can be matched with the mentioned cost estimation "reserve". Thus, it is not absolutely clear if these savings are caused by BIM only or by other factors as well.

In addition, taking into account the BLM concept, it is important to understand that costs at a particular stage of a project (design or construction stages) can be increased by investment in implementation of information modelling. However, the effects of BIM, like any other innovation, might accumulate and manifest themselves at all stages of the real estate asset lifecycle.

For instance, specialists of High-altitude and Underground Structures Design Bureau (DB H\&US) in St. Petersburg (top-management of DB H\&US, personal communication, July 30, 2018) state that designing with the use of BIM increases cost, time and labour intensity of the Project Documentation stage, whereas at the Working Documentation stage these indicators drastically fall a result of reducing the possible number of collisions being detected at the construction stage. Figures 3 and 4 illustrate these advantages.

As a result, the designers at High-altitude and Underground Structures Design Bureau (designers at DB H\&US, personal communication, July 30, 2018) note that they are interested in using BIM only when they sign a contract for the full design cycle. The more of a project lifecycle stages a stakeholder is responsible for, the more tangible benefits of using BIM they have. Thus, full-cycle companies are more interested in implementing information modelling technologies and are able to actually gain the effects of construction cost and time reduction, as well as of profit increase by an average of $15 \%$ at a company level (Moscow State University of Civil Engineering (National Research University), 2016). 


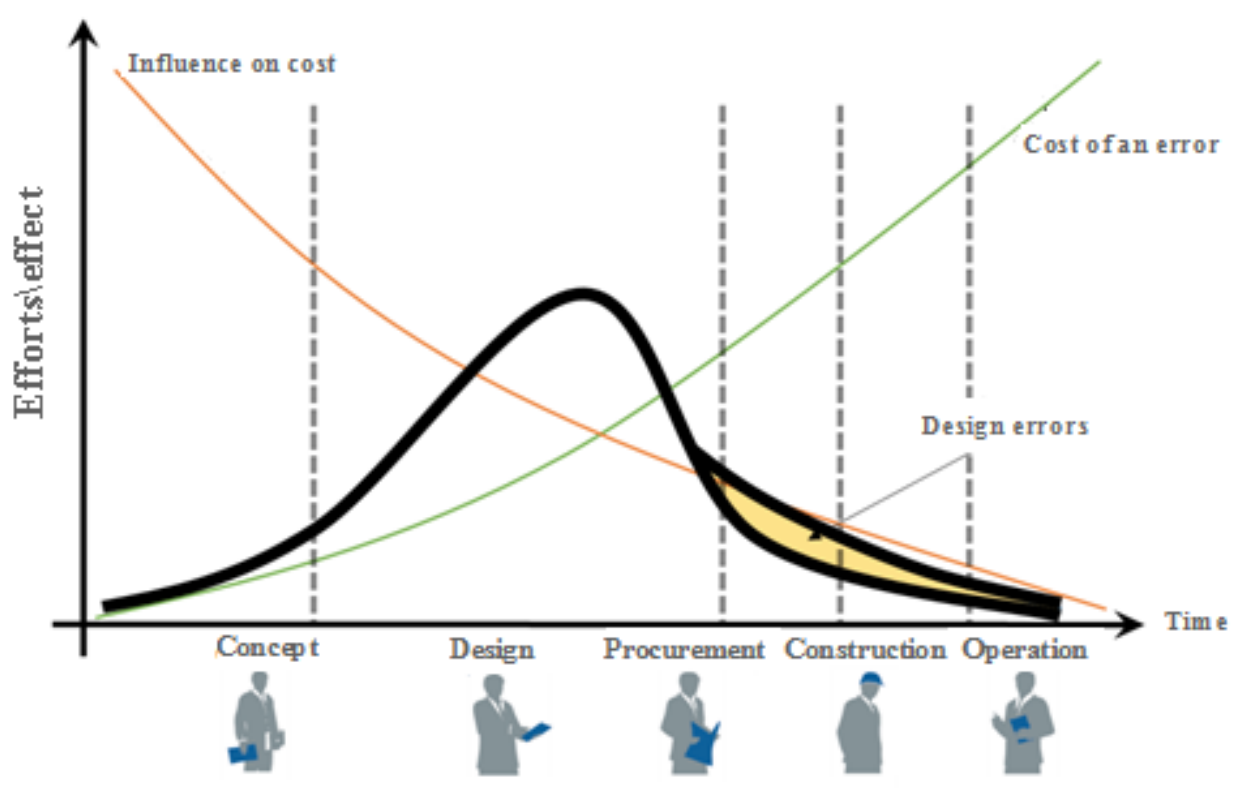

Fig. 3. Traditional design cost spread over a real estate asset lifecycle (developed by the authors, based on the data provided by DB H\&US).

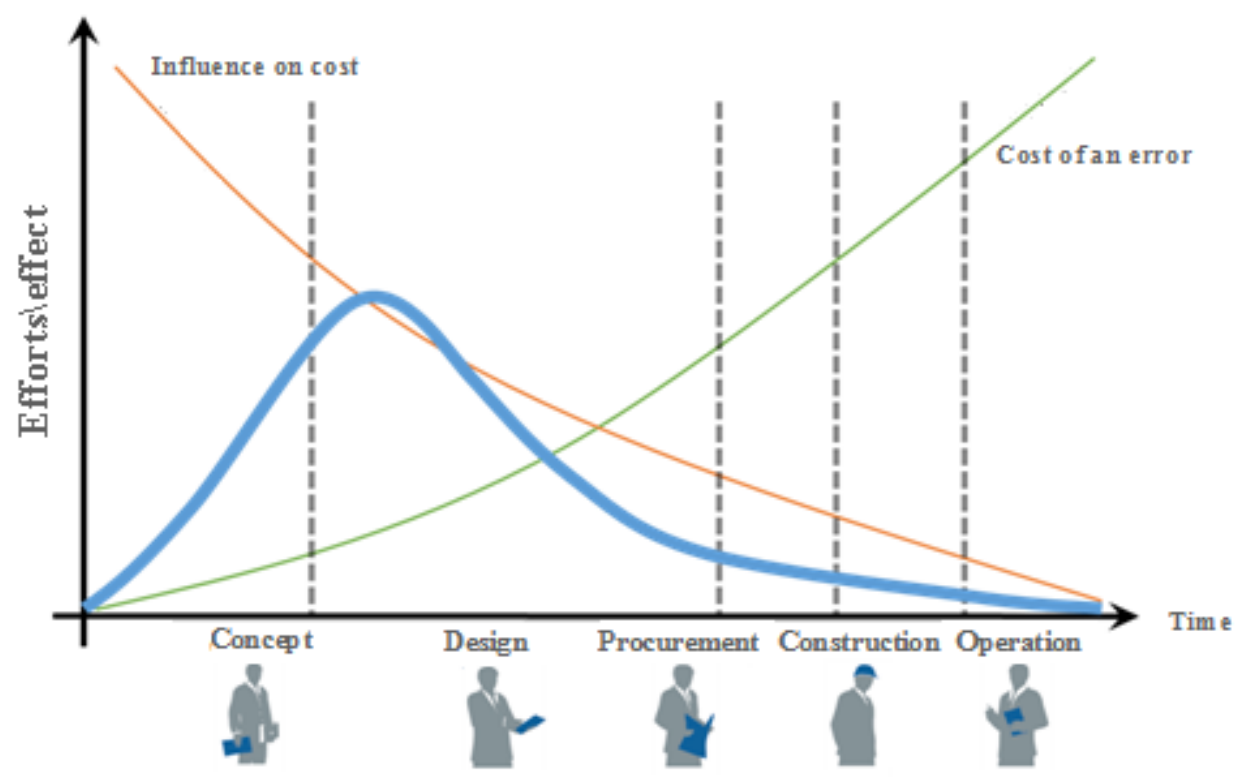

Fig. 4. Costs of design within BIM spread over a real estate asset lifecycle (developed by the authors, based on the data provided by DB H\&US).

As far as the non-economic effects mentioned by BIM users are concerned, it should be noted that in Russia most companies that actively implement and use information modelling technologies are sceptical about them ((Novokovskii, 2015). This is attributed to the maturity level of information modelling processes according to the model proposed by Mark Bew and Mervyn Richards (Korol, 2015). Russian 
companies are currently mastering level 1 , while world leaders using BIM are already about to reach level 3, which is focused on the concept of BLM and characterised by the effects described above.

\section{RESULTS}

As a result of the present research, differences in the levels of development of information modelling processes in Russia and the world have been revealed. Using the international experience of BIM and the concept of real estate asset lifecycle management as a basis, it is necessary to identify a set of digital methods and tools that correspond to the goals of each phase of the lifecycle and to the interests of all participants of investment and construction activities.

A number of studies have been conducted at the Department of Project and Programs Management at Plekhanov Russian University of Economics, which enable systematization of up-to-date and highly relevant digital methods and tools used in the process of information modelling of a real estate asset corresponding to the goals of each phase of its lifecycle (see Table 1).

Table 1. Application of Digital Technologies at Different Stages of a Real Estate Asset Lifecycle (developed by the authors)

\begin{tabular}{|c|c|c|c|c|c|}
\hline Lifecycle phase & $\begin{array}{c}\text { Research } \\
\text { (Concept) }\end{array}$ & Design & Construction & $\begin{array}{c}\text { Use } \\
\text { (Operation) }\end{array}$ & Excess \\
\hline Information modelling & + & + & + & + & + \\
\hline 3D-printing & + & + & + & + & + \\
\hline $\begin{array}{c}\text { Robotization } \\
\text { Blockchain } \\
\text { technologies }\end{array}$ & + & + & + & + & + \\
\hline $\begin{array}{c}\text { Cloud computing } \\
\text { technologies }\end{array}$ & & + & & + & + \\
\hline $\begin{array}{c}\text { GIS technologies } \\
\text { Mining }\end{array}$ & + & & & + & + \\
\hline Data centres & & & & + \\
\hline
\end{tabular}

However, the lack of an effective regulatory framework for information modelling in Russia remains a key problem. Despite the development of the series of Codes and State Standards GOST R (ISO) "Building Information Modelling", as well as of corporate standards by some organisations, introduction of BIM technologies is mainly constrained by the inability to use digital models by some participants of investment and construction projects (for example, customers, contractors, builders). Meanwhile, the goals of the government, according to the experience of the leading countries in the field of application and development of information modelling technologies, should be standardization, control, stimulation and active promotion of the effects arisen from using BIM, development and 
support of educational programmes in the field of training specialists with up-todate skills and qualifications.

Given the fact that transition to using BIM technologies is burdening for many companies in terms of additional expenditure, and the information model of a real estate asset created at a design stage is valuable at all stages of its lifecycle, it can contribute to the development of public-private partnership mechanisms in construction (Kallaur, 2018) with the government investing in the implementation of information modelling technologies.

\section{CONCLUSION}

Given the transitional stage of development of BIM processes in Russian companies, as well as the need for large-scale innovative development of the construction industry in the digitalization era, conditions for effective implementation of BIM for all participants of investment and construction activities have been defined in this paper.

Information modelling in construction accelerates and expands the possibilities of searching, justifying and implementing innovations in real estate asset lifecycle management. Creation of a BIM platform is becoming an important factor for improving productivity in the construction industry, which is currently mediumtech and low-innovative in Russia.

\section{ACKNOWLEDGEMENTS}

The research has been supported by the Russian Foundation for Basic Research (RFBR) within the scientific project "Development of Digital Economy Methods within an Innovative System of Investment and Construction Projects Management”, No. 18-010-01040.

\section{REFERENCES}

Eroshkin, S. Yu., Kallaur, G. Yu., \& Papikyan, L. M. (2017). Integrated use of BIM technologies for project management (Integrirovannoye ispolzovaniye BIM-tekhnologiy $\mathrm{v}$ tselyakh upravleniya proyektami). Vestnik MGTU STANKIN, 4 (43), 125-130.

GOST R, (2016). Building information models. Information delivery manual. Methodology and format (GOST R 57310-2016, ISO 29481-1:2010). Retrieved from http://docs.cntd.ru/document/1200142710

GOST R, (2016). Guidelines for knowledge libraries and object libraries (GOST R 57309-2016, ISO 16354:2013). Retrieved from http://docs.cntd.ru/document/1200142712

GOST R, (2017). Building information modeling. General principles for the development of building and constructions information modeling standards (GOST R 57563-2017/ISO/TS 12911:2012). Retrieved from http://docs.cntd.ru/document/1200146763

GOST R, (2017). Model of construction works data organization. The structure of project information management (GOST R ISO 22263-2017). Retrieved from http://docs.cntd.ru/document/1200146216

Kallaur, G. Yu. (2018). Obosnovanie investitsii v tekhnologii informatsionnogo modelirovaniia. Ekonomika stroitelstva, 1 (49), 27-38.

Korol, M. (2015). Britantsy soobshchili miru, chto takoe BIM urovnia 3: eto - Digital Built Britain. Retrieved from http://isicad.ru/ru/articles.php?article_num $=17570$ 
McGraw Hill Construction. Smart Market Report "The Business Value of BIM for Construction in Major Global Markets: How contractors around the world are driving innovation with building information modeling". Retrieved from http://images.marketing.construction.com/Web/DDA/\%7B29cf4e75-c47d-4b73-84f7c228c68592d5\%7D_Business_Value_of_BIM_for_Construction_in_Global_Markets.pdf

Moscow State University of Civil Engineering (National Research University). (2016). Otsenka primeneniia BIM-tekhnologii v stroitelstve. Rezultaty issledovaniia effektivnosti primeneniia BIM-tekhnologii v investitsionno-stroitelnykh proektakh rossiiskikh kompanii

Novokovskii K. (2015). Tak li effektivny BIM tekhnologii proektirovaniya, kak ob etom govoriat? Retrieved from https://maistro.ru/articles/stroitelnye-konstrukcii.-proektirovanie-iraschet/obzor-bim-tehnologij

Pravitelstvo Rossiiskoi Federatsii. (2011). Strategiia innovatsionnogo razvitiia RF na period do 2020 goda № 2227-r. Retrieved from http://ac.gov.ru/files/attachment/4843.pdf

Primenenie BIM-tekhnologii pri stroitelstve Dongdaemun Design Plaza - krupneishego v mire zdaniia nepravilnoi formy (2018). Tekhnologii Stroitelstva. Retrieved from https://ardexpert.ru/article/11548

Rising to new heights with BIM. Shanghai Tower owner champions BIM for design and construction of one of the world's tallest (and greenest) buildings. Retrieved from Autodesk: https://damassets.autodesk.net/content/dam/autodesk/www/case-studies/shanghaitower/shanghai-tower-customer-story.pdf

Sukhorukov, A. I., Eroshkin, S. Y., Kallaur, G. Y., and Papikyan, L. M. (2018). Tekhnologii informatsionnogo modelirovaniia vsekh etapov zhiznennogo tsikla tekhnicheskogo obieekta. Vestnik mashinostroyeniia, 4, 84-86.

The Ministry of Construction, Housing and Communal Services of The Russian Federation. (2014). Prikaz "Ob utverzhdenii Plana poetapnogo vnedreniya tekhnologiy informatsionnogo modelirovaniya v oblasti promyshlennogo i grazhdanskogo stroitelstva” № 926 ot 29 dekabrya 2014 goda. Retrieved from http://docs.cntd.ru/document/420245345

The Ministry of Construction, Housing and Communal Services of The Russian Federation. (2017). A series of Codes "Building Information Modeling". Retrieved from http://rustandards.ru/documents/5e6ffc94e153d537474e/text

\section{AUTHORS' SHORT BIOGRAPHIES}

Irina Vladimirova graduated from Moscow Institute of Civil Engineering named after V.V. Kuybyshev. She received a Doctoral degree, defending the Doctoral Thesis "Investment and Construction Activity and Social and Economic Development of Territories" in 2010. She has over 30 years of work experience in the specialised profession. She is currently a Professor at Project and Programme Management Department at Plekhanov Russian University of Economics, Moscow, Russia. She is also a Supervisor of Master degree programme "Management of Investment and Construction Projects and Programmes" and Corresponding Member of the International Academy of Investment and Construction. Her scientific interests are methodology of investment and construction projects management, investment feasibility studies, sustainable development of territories, cost engineering, "green" construction and digital methods of management.

Tel.: +74992378791

E-mail: annaromany@yandex.ru

Address: 1/2 12 Derbenevskaya nab., Moscow, 115114, Russia

ORCID iD: https://orcid.org/0000-0001-6138-5053

Galina Kallaur graduated from Plekhanov Russian University of Economics in 2004. In 2009, she defended the Thesis for a degree of Candidate of Economic Sciences with major "Economy and Management of the National Economy: Economy, Organization and Management of the Enterprises, Branches, Complexes (Construction)" and received the degree of Candidate of Economic Sciences. 
She has 13 years of work experience in the specialised profession. She is currently an Associate Professor at Project and Programme Management Department at Plekhanov Russian University of Economics, Moscow, Russia. Her scientific interests cover the sphere of real estate development, development of territories, modern methodologies and tools of project management and innovative approaches to construction development.

Tel.: +7(919)411-23-70

E-mail: kallaur_galina@mail.ru

Address: 36 Stremiannyi lane, Moscow, 117997, Russia

ORCID iD: https://orcid.org/0000-0001-9068-8475

Kseniia Bareshenkova graduated from Plekhanov Russian University of Economics in 2010. At present, she is doing a post-graduate course at Project and Programme Management Department at Plekhanov Russian University of Economics and working on the thesis for the degree of Candidate of Economic Sciences on the topic "The Organisational and Economic Mechanism of Management of Engineering Activities in Construction". She is currently a Leading Specialist at Project and Programme Management Department at Plekhanov Russian University of Economics, Moscow, Russia. She has 3 years of work experience in the specialised profession. Her scientific interests include investment and construction engineering, cost engineering, development of digital economy methods and project management.

Tel.: +74992378791

E-mail: ks-bareshenkova@yandex.ru

Address: 31/2/81 Nikitinskaya Str., Moscow, 105122, Russia

ORCID iD: https://orcid.org/0000-0003-2972-5788 